\title{
Yield Components, Yield and Residual Fertility Status of the Soil after Rice as Influenced by Integrated Nitrogen Management
}

\author{
A. Sowjanya* and M. Sree Rekha \\ Department of Agronomy, Agricultural College, Bapatla, India \\ *Corresponding author
}

A B S T R A C T

\begin{tabular}{|c|c|}
\hline $\begin{array}{l}\text { Ke y w or d s } \\
\text { Integrated nitrogen, } \\
\text { Yield and fertility } \\
\text { levels }\end{array}$ & $\begin{array}{l}\text { A field experiment was conducted at Agricultural College Farm, Bapatla, during kharif } \\
2015-16 \text { to find out the response of transplanted rice under three levels of inorganic } \\
\text { nitrogen in combination with organic manures viz., poultry manure, FYM and neemcake at } \\
75,100 \text { and } 125 \text { per cent RDN. The highest yield components and yield of rice was } \\
\text { recorded with application of } 50 \text { per cent } \mathrm{N} \text { applied as inorganic and remaining } 50 \text { per cent }\end{array}$ \\
\hline Art & \\
\hline $\begin{array}{l}\text { Accepted } \\
23 \text { March } \\
\text { Available } \\
10 \text { April }\end{array}$ & $\begin{array}{l}\text { availability was obtained with } 125 \text { per cent } \mathrm{N}(50 \text { per cent inorganic }+50 \text { per cent FYM), } \\
\text { the highest soil } \mathrm{P} \text { availability with } 125 \text { per cent } \mathrm{N}(50 \text { per cent inorganic }+50 \text { per cent } \\
\text { poultry manure }) \text { and the highest soil } \mathrm{K} \text { availability was recorded with } 125 \text { per cent } \mathrm{N}(50 \\
\text { per cent inorganic }+50 \text { per cent neemcake). }\end{array}$ \\
\hline
\end{tabular}

\section{Introduction}

Rice is one of the most important food grains produced and consumed all over the world. Global rice demand is expected to rise from 439 million tonnes in 2010 to 496 million tonnes in 2020 and further increase to 553 million tonnes in 2035 (FAO, 2013). This shows an overall increase of 26 per cent in the next 25 years, thus global rice yields must raise much faster. Among the rice growing countries, India has the largest area (44 million hectares) and it is the second largest producer (131 million tonnes) of rice next to China (197 million tonnes). The rice productivity in India is $2.98 \mathrm{t} \mathrm{ha}^{-1}$, while the world average is $4.25 \mathrm{t} \mathrm{ha}^{-1}$ (IRRI, 2011). To meet the food requirement of the growing population, the rice production has to be enhanced with good management practices. Nitrogen (N) application is essential to realize the yield potential of high yielding varieties of rice.

Adding inorganic fertilizers is a good way of correcting the deficiency of nutritional elements, but they not only add to the cost of production but often are not available to meet the demands of farmers. Although the fertilizers are very effective in increasing yield, they may deteriorate the soil structure and pollute the groundwater. Integrated nitrogen supply concept involving both organic and inorganic sources based on their availability and cost effectiveness is well adopted and judicious combination of these 
two sources has been found to mutually reinforce the efficiency of both the sources resulting in higher productivity and soil fertility. In the light of the above context this study was planned to find out the performance of rice under three inorganic nitrogen levels and combination with organic manures like FYM. Poultry manure and neemcake.

\section{Materials and Methods}

An experiment was conducted at Agricultural College Farm, Bapatla during kharif 2015-16 on clay soils, which was slightly alkaline in reaction, organic carbon and nitrogen were medium, available phosphorous and potassium were high. The experiment consisted of twelve treatments viz., 75 per cent recommended dose of nitrogen i.e. $90 \mathrm{~kg} \mathrm{ha}^{-1}\left(\mathrm{~T}_{1}\right), 100$ per cent recommended dose of nitrogen i.e. 120 $\mathrm{kg} \mathrm{ha}^{-1}\left(\mathrm{~T}_{2}\right), 125$ per cent recommended dose of nitrogen i.e. $150 \mathrm{~kg} \mathrm{ha}^{-1}\left(\mathrm{~T}_{3}\right), 50$ per cent $\mathrm{N}$ of $\mathrm{T}_{1}$ through inorganic fertilizer +50 per cent $\mathrm{N}$ of $\mathrm{T}_{1}$ through FYM $\left(\mathrm{T}_{4}\right), 50$ per cent $\mathrm{N}$ of $\mathrm{T}_{1}$ through inorganic fertilizer +50 per cent $\mathrm{N}$ of $\mathrm{T}_{1}$ through poultry manure $\left(\mathrm{T}_{5}\right), 50$ per cent $\mathrm{N}$ of $\mathrm{T}_{1}$ through inorganic fertilizer +50 per cent $\mathrm{N}$ of $\mathrm{T}_{1}$ through neemcake $\left(\mathrm{T}_{6}\right), 50$ per cent $\mathrm{N}$ of $\mathrm{T}_{2}$ through inorganic fertilizer +50 per cent $\mathrm{N}$ of $\mathrm{T}_{2}$ through FYM $\left(\mathrm{T}_{7}\right), 50$ per cent $\mathrm{N}$ of $\mathrm{T}_{2}$ through inorganic fertilizer +50 per cent $\mathrm{N}$ of $\mathrm{T}_{2}$ through poultry manure $\left(\mathrm{T}_{8}\right), 50$ per cent $\mathrm{N}$ of $\mathrm{T}_{2}$ through inorganic fertilizer +50 per cent $\mathrm{N}$ of $\mathrm{T}_{2}$ through neemcake $\left(\mathrm{T}_{9}\right), 50$ per cent $\mathrm{N}$ of $\mathrm{T}_{3}$ through inorganic fertilizer +50 per cent $\mathrm{N}$ of $\mathrm{T}_{3}$ through FYM $\left(\mathrm{T}_{10}\right), 50$ per cent $\mathrm{N}$ of $\mathrm{T}_{3}$ through inorganic fertilizer +50 per cent $\mathrm{N}$ of $\mathrm{T}_{3}$ through poultry manure $\left(\mathrm{T}_{11}\right), 50$ per cent $\mathrm{N}$ of $\mathrm{T}_{3}$ through inorganic fertilizer +50 per cent $\mathrm{N}$ of $\mathrm{T}_{3}$ through neemcake $\left(\mathrm{T}_{12}\right)$.

The experiment was laid out in a Randomized block design and replicated thrice. Well decomposed farmyard manure with 0.5 per cent nitrogen, poultry manure with 1.5 per cent and neem cake with 1.8 per cent nitrogen were used as organic sources and they were applied as per the treatment combinations ten days before transplanting. The inorganic nitrogen was applied through urea as per treatments while recommended dose of phosphorous (60 kg $\mathrm{P}_{2} \mathrm{O}_{5} \mathrm{ha}^{-1}$ ) and potassium (40 $\mathrm{kg} \mathrm{K}_{2} \mathrm{O} \mathrm{ha}{ }^{-1}$ ) were applied through single superphosphate and muriate of potash, respectively uniformly to all the treatments. Entire quantity of phosphorus and potassium and one third of the $\mathrm{N}$ were applied as basal at the time of transplanting. Remaining $\mathrm{N}$ was applied in two equal splits, one at active tillering stage and the other at panicle initiation stage. Thirty two days old seedlings were transplanted in experimental plots keeping two seedlings per hill by adopting a spacing of $20 \mathrm{~cm}$ x $15 \mathrm{~cm}$. Recommended agronomic practices and plant protection measures were followed.

\section{Results and Discussion}

\section{Yield components and yield}

Yield components and yield were significantly influenced by different sources of nitrogen and presented in table 1. Among all treatments, significantly highest yield components viz., number of panicles $\mathrm{m}^{-2}$, number of grains and filled grains panicle ${ }^{-1}$ were recorded in the treatment $T_{11}$ which was comparable with $T_{3}$ and $T_{2}$ followed by $T_{12}$. Similar results were also recorded in the grain yield and 1000 grain weight was not significantly influenced by the different nitrogen management treatments. The better performance of the poultry manure treated plot might be due to higher concentration of macro and micro nutrients and steady nutrient release compared to other organic manures. The enhanced and continuous supply of nutrients by the integrated application might have led to better tillering ability and conversion of total number of tillers to productive tillers increasing the number of panicles $\mathrm{m}^{-2}$. 


\section{Int.J.Curr.Microbiol.App.Sci (2018) 7(4): 2801-2806}

Table.1 Yield components and yield of rice as influenced by combined use of organics and inorganics in transplanted rice

\begin{tabular}{|c|c|c|c|c|c|}
\hline Treatments & $\begin{array}{l}\text { Total no. of } \\
\text { panicles } \text { m }^{-2}\end{array}$ & $\begin{array}{l}\text { Total number of } \\
\text { grains panicle }\end{array}$ & $\begin{array}{l}\text { Number of filled } \\
\text { grains panicle }^{-1}\end{array}$ & $\begin{array}{c}\text { Test weight } \\
\text { (g } 1000 \text { grains }^{-1} \text { ) }\end{array}$ & $\begin{array}{l}\text { Grain yield } \\
\left.\text { (kg ha }^{-1}\right)\end{array}$ \\
\hline $\mathbf{T}_{1}$ & 214.0 & 136.0 & 121.6 & 14.8 & 3313 \\
\hline$\overline{T_{2}}$ & 317.4 & 181.7 & 155.7 & 14.8 & 5530 \\
\hline $\mathbf{T}_{3}$ & 321.0 & 182.1 & 156.8 & 15.0 & 5604 \\
\hline $\mathbf{T}_{4}$ & 166.7 & 110.3 & 101.2 & 15.8 & 2641 \\
\hline $\mathbf{T}_{5}$ & 170.0 & 115.3 & 104.6 & 15.6 & 2752 \\
\hline $\mathrm{T}_{6}$ & 183.0 & 113.5 & 102.6 & 15.5 & 2835 \\
\hline$\overline{\mathrm{T}_{7}}$ & 207.0 & 132.7 & 121.5 & 15.3 & 3180 \\
\hline $\mathrm{T}_{8}$ & 248.9 & 155.3 & 137.3 & 15.3 & 4126 \\
\hline $\mathrm{T}_{9}$ & 247.3 & 154.8 & 137.6 & 14.8 & 4024 \\
\hline $\mathbf{T}_{10}$ & 250.3 & 157.3 & 139.4 & 15.1 & 4196 \\
\hline $\mathbf{T}_{11}$ & 321.7 & 183.3 & 157.8 & 15.0 & 5680 \\
\hline $\mathbf{T}_{12}$ & 284.5 & 158.3 & 140.1 & 15.9 & 4870 \\
\hline SEm \pm & 10.46 & 7.29 & 5.12 & 0.43 & 224.9 \\
\hline CD (0.05) & 30.7 & 21.4 & 15.0 & NS & 660 \\
\hline $\mathrm{CV}(\%)$ & 7.4 & 8.5 & 7.0 & 5.0 & 10.0 \\
\hline
\end{tabular}


Table.2 Available $\mathrm{N}, \mathrm{P}_{2} \mathrm{O}_{5}$ and $\mathrm{K}_{2} \mathrm{O}$ status $\left(\mathrm{kg} \mathrm{ha}^{-1}\right)$ of soil after harvest of rice as influenced by combined use of organics and inorganics in transplanted rice

\begin{tabular}{|c|c|c|c|}
\hline \multirow{2}{*}{ Treatments } & \multicolumn{3}{|c|}{ A vailable nutrients } \\
\hline $\mathrm{T}_{\mathbf{1}}$ & Nitrogen & Phosphorus & Potassium \\
\hline $\mathrm{T}_{\mathbf{2}}$ & 200.7 & 32.7 & 350.4 \\
\hline $\mathrm{T}_{\mathbf{3}}$ & 218.3 & 31.5 & 347.2 \\
\hline $\mathrm{T}_{\mathbf{4}}$ & 190.0 & 33.0 & 345.3 \\
\hline $\mathrm{T}_{\mathbf{5}}$ & 185.4 & 42.0 & 383.5 \\
\hline $\mathrm{T}_{\mathbf{6}}$ & 182.7 & 41.1 & 421.7 \\
\hline $\mathrm{T}_{\mathbf{7}}$ & 237.3 & 35.4 & 405.0 \\
\hline $\mathrm{T}_{\mathbf{8}}$ & 220.6 & 53.4 & 391.6 \\
\hline $\mathrm{T}_{\mathbf{9}}$ & 221.6 & 33.5 & 396.6 \\
\hline $\mathrm{T}_{\mathbf{1 0}}$ & 312.4 & 28.9 & 423.7 \\
\hline $\mathrm{T}_{\mathbf{1 1}}$ & 248.0 & 64.5 & 467.1 \\
\hline $\mathrm{T}_{\mathbf{1 2}}$ & 280.9 & 45.8 & 509.0 \\
\hline $\mathrm{SE} \mathbf{m} \pm$ & 10.53 & 2.65 & 13.73 \\
\hline $\mathrm{CD}(\mathbf{0 . 0 5}$ & 30.9 & 7.8 & 40.3 \\
\hline $\mathrm{CV}(\boldsymbol{\%})$ & 8.0 & 12.9 & 7.0 \\
\hline
\end{tabular}

The effect of nitrogen on seed filling is assimilate accumulation which is also a primary function and in turn, facilitates higher $\mathrm{N}$ assimilation with adequate supply of photosynthates to grain (Kumar et al., 2008).

The contribution of carbohydrates from photosynthetic activity for longer period might have resulted in efficient translocation of food material into grain there by increasing the number of filled grains panicle ${ }^{-1}$.Such an increase in yield components and yield with poultry manure was also reported by Sangeetha et al., (2010) and Ananda et al., (2006). The lowest yield components and yield were recorded in treatments $\mathrm{T}_{6}, \mathrm{~T}_{5}$ and $\mathrm{T}_{4}$ might be due to lower dosage that lead to the less availability of nutrients.

\section{Availability of nutrients}

Among all the treatments $\mathrm{T}_{10}$ treatment recorded the maximum nitrogen availability (312.4 $\mathrm{kg} \mathrm{ha}^{-1}$ ) after harvest of the rice crop which might be due to decomposition of organic matter added through FYM by slow mineralization that lead to increased availability of nitrogen status of the soil.

Due to increase in microbial activity in the presence of organic matter, it released the available form of native, unavailable form of nutrients. Consequently, available nutrients status was enhanced Singh et al., (2006) and Rajanna et al., (2012) also reported similar results (Table 2).

The $\mathrm{T}_{11}$ treatment recorded maximum (64.5 $\mathrm{kg} \mathrm{ha}^{-1}$ ) available $\mathrm{P}$ after harvest of the rice crop and it was followed by $\mathrm{T}_{8}$ and proved significantly superior to rest of the treatments. This might be due to poultry manure having highest phosphorous content (2.63 per cent) when compared other sources viz., FYM 0.25 per cent and neemcake 1.4 per cent (Reddy and Reddi, 2015). The increased available $\mathrm{P}$ content of soil might be due to release of $\mathrm{CO}_{2}$ and organic acids during decomposition. This 
helps in solubilizing the native soil $\mathrm{P}$. The organic matter may also reduce the fixation of phosphate by providing protective cover on sesqueoxides and chelating cations like $\mathrm{Ca}^{2+}$ and $\mathrm{Mg}^{2+}$ (when applied along with inorganic fertilizer) which in turn enhanced the availability of P (Singh et al., 2008). Lowest $\mathrm{P}$ availability was observed in the inorganic treatments viz., $\mathrm{T}_{2}$ and $\mathrm{T}_{3}$ which might be due to higher grain and straw yield of the crop, which in turn might have resulted in extraction of the most of soil nutrients.

The maximum potassium content in the treatment $\mathrm{T}_{12}$ might be due to the lesser yields recorded which would have led to lesser uptake of potassium even though it received 125 per cent RDN through organics and inorganics and when compared to $\mathrm{T}_{11}$. The beneficial effect of neemcake on available potassium might be due to the reduction of potassium fixation, solubilisation and release due to the interaction of organic matter with clay besides the direct potassium addition to the potassium pool of soil.

The available nutrients in soil increased due to treatments incorporating either total or part of nutrients through organic sources as compared to inorganic sources. This may be due to the release of aliphatic and aromatic hydroxy acids, humates and lignins from organic manures which would release the nutrients into the soil (Aruna et al., 2012).

It can be concluded that combined application of 50 per cent as inorganic and other 50 per cent as organic source i.e., poultry manure @ 125 per cent RDN $\left(\mathrm{T}_{11}\right)$ resulted in comparable yield with $125 \mathrm{RDN}$ alone and was thus found to be the best combination for increasing the productivity of rice and also resulted in increased residual fertility levels of the soil compared to different sources i.e., neemcake and FYM and alone application of inorganic fertilizers.

\section{References}

Ananda, M.G., Ananda, M.R., Reddy, V.C and Ajayakumar, M.Y. 2006. Influence of different organic sources on yield and its components and benefit cost ratio of paddy (Oryza sativa L.) and groundnut (Arachis hypogaea L.) in paddy groundnut cropping system. Crop Research. 31 (3): 329-333.

Aruna, P., Prabhakara Reddy, G and Karuna Sagar, G. 2012. Effect of integrated nitrogen management on growth, yield, quality and post - harvest nutrient status of soil in aerobic rice (Oryza sativa L.). Crop Research. 43 (1, 2 \& 3): 1-4.

FAO. 2013 Global rice production. In: http: // fao.org / news / story / jp / item.164713 / code.

IRRI. 2011 Trends in the rice economy. In: http:// beta.irri.org/ solutions/ index.php

Kumar, S. G., Muthukrishnan, P., Ramaswamy, S and Chandragiri, K.K. 2008. Effect of non - conventional system of cultivation with varied $\mathrm{N}$ levels on growth, yield and water management of rice (Oryza sativa L.). Madras Agricultural Journal. 95 (7-12): 343-352.

Rajanna, G.A., Murali, K., Pradeep Gopakkali, Pradeep Nayak, Sudakara, T.M and Lakshmipathy, R.N. 2012. Effect of different sources and time of application of organic manures on residual fertility and nutrient balance in aerobic rice (Oryza sativa L.). Crop Research. 43 (1, 2 \& 3): 5-9.

Reddy, T.Y and Reddi, G.H.S. 2015. Principles of Agronomy. Kalyani publishers. Ludhiana. pp: 208.

Sangeetha, S.P., Balakrishna and Bhuvaneshswari, J. 2010. Organic nutrient sources on growth and yield of rice. Madras Agricultural Journal. 97 (79): 251-253. 
Singh F., Ravindra, K and Samir, P. 2008. Integrated nutrient management in rice-wheat cropping system for sustainable productivity. Journal of the Indian Society of Soil Science. 56 (2): 205-208.
Singh, R.P., Yadav, P.K., Singh, R.K., Singh, S.N., Bisen, M.K and Singh, J. 2006. Effect of chemical fertilizer, FYM and biofertilizer on performance of rice and soil properties. Crop Research. 32 (3): 283-285.

\section{How to cite this article:}

Sowjanya, A. and Sree Rekha, M. 2018. Yield Components, Yield and Residual Fertility Status of the Soil after Rice as Influenced by Integrated Nitrogen Management. Int.J.Curr.Microbiol.App.Sci. 7(04): 2801-2806. doi: https://doi.org/10.20546/ijcmas.2018.704.318 